\title{
PROSPEK EKONOMI SYARI'AH MELALUI PRODUK MUDARABAH DALAM MEMPERKUAT SEKTOR RIIL
}

\author{
Siti Mujibatun, IAIN Walisongo Semarang
}

\begin{abstract}
Mudarabah, as an icon of commercial products in Shari'ah Economic, factually proven toughness in facing the financial crisis during this time. By placing the product mudarabah proportionally in the financial business institutions have a significant impact on economic sustainability in strengthening the real sector. Some of the benefits include Mudarabah product; has a rate of return higher than the interest rate applicate on interest bank, based on "production-based" by transactions based on real assets and not solely on the paperwork that are derivatives and free from elements of speculation. Mudarabah based on production. Therefore, the financial crisis can be minimized because the balance sheet of company is stable relatively. To maintain it in the real sector, government support in the form of policies by strengthening the role of national banking intermediation in the financial and real sector investment is needed to minimize the level of unemployment.
\end{abstract}

Keywords : Economic Shariah, Mudarabah, Real Sector.

\section{Pendahuluan}

Menurut pendapat Qodri Abdillah Azizi, ekonomi syari'ah sebagai sebuah ilmu dalam perkembangan aliran pemikiran Islam sejak awal abad dua Hijriyah termasuk pada bagian Fiqh Muamalah. Beliau menjelaskan bahwa "fiqh" (hukum Islam) adalah suatu ilmu yang mempelajari aturan-aturan hukum yang berhubungan dengan perbuatan para mukallaf yang dipetik dari dalil-dalil syara' (Qur'an dan hadis Nabi saw) secara rinci atau:

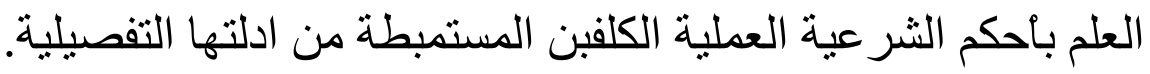

Adapun pengertian Fiqh Muamalah identik dengan ekonomi Islam yang merupakan salah satu cabang ilmu fiqh yang membahas tentang 
Prospek Ekonomi Syariah Melalui Produk Mudarabah

perbuatan para mukallaf meliputi hak-hak kebendaan, hak milik (property) dan juga tentang akad (perikatan). (Qodri, 2003: 176-177)

Pembagian fiqh berdasarkan pada pembahasan yang terdapat dalam kitab-kitab mu'tabar terdiri dari:

1. Fiqh Ibadah

2. Fiqh Munakahat

3. Fiqh Muamalah

4. Fiqh Jinayat

5. Fiqh Siyasah dan Jihad

6. Fiqh Mawaris

Terlepas dari berbagai pendapat baik yang pro maupun yang kontra terhadap epistimologi ekonomi Islam (Syari'ah), pada kenyataannya dewasa ini penguatan terhadap eksistensi ekonomi Islam telah berkembang sangat pesat terutama melalui industri pendidikan dan juga lembaga-lembaga bisnis dan keuangannya misalnya: Lembaga Jasa Keuangan Syari'ah, lembaga perbankan Syari'ah dan sejenisnya.

Beberapa prinsip yang harus ditegakkan dalam ekonomi Syari'ah menurut Haedar Naqvi (2003, 37-38) selain ketauhidan atau Ilahiyah, equilibrium (keadilan), kehendak bebas (free will) dan tanggung jawab (responsibility). Terdapat pula prinsip yang harus melekat dan sebagai ikon dalam praktik ekonomi berbasis Syari'ah yaitu: Menghindarkan gharar (ketidakjelasan), maisir (perjudian), riba serta berbasis pada usaha yang halal ${ }^{1}$. Untuk mencapai hal tersebut diperlukan adanya usaha atau kegiatan yang terbebas dari unsurunsur tersebut artinya, bahwa dalam rangka mewujudkan serta meningkatkan kesejahteraan ekonomi masyarakat, perekonomian perlu dibangun berdasarkan pada sebuah tatanan yang bersih dari ketidakjelasan, permainan untung-untungan dan juga penindasan (kezaliman) yang bertentangan dengan prinsip-prinsip ketauhidan (Ilahiyyah).

\footnotetext{
${ }^{1}$ Prinsip Ilahiyyah (lihat QS 6 ayat 162), equilibrium (keadilan) (lihat QS 16 ayat 90), kehendak bebas (free will) (lihat QS 13ayat 11), tanggung jawab (responsibility) (lihat QS 6 ayat 164). Menghindarkan gharar (ketidakjelasan) (lihat QS 4 ayat 29), maisir (perjudian) (QS 5 ayat 90), riba (QS 2 ayat 275) serta usaha yang halal (QS 2 ayat 168)
} 
Hal ini sebagaimana disampaikan Menkop dan UKM Syarief Hasan pada acara Workshop Nasional Pra Konvensi Nasional Anggota Pusat Komunikasi Ekonomi Syariah (PKES) di Aula Kemenkop UKM Jakarta belum lama ini. Syarief menilai, kinerja LKS termasuk perbankan syariah-nya, rata rata memiliki FDR (Financing to Deposit Ratio) sangat tinggi dan pembiayaanya disalurkan sebagian besar pada sektor UMKM (Usaha Mikro Kecil Menengah) dan bukan untuk bermain (spekulasi) jual beli di pasar saham derivative, membuktikan bahwa LKS (Lembaga keuangan Syari'ah) dan perbankan syariah merupakan real sektor bases financial yang jauh berbeda dengan LKK (Lembaga Keuangan Konvensional).

Di lain pihak, pemerintah melalui Kemenkop UKM telah menerbitkan Keputusan Menteri Negara Koperasi dan UKM No. 91/2004 tentang petunjuk Pelaksanaan Kegiatan Usaha untuk mendorong UMKM (Usaha Mikro Kecil Menengah), antara lain melalui Koperasi Jasa Keuangan Syariah (KJKS) yang disertai dengan instrumen pedoman standar operasional manajemen KIKS/UIKS Koperasi, pedoman penilaian kesehatan KIKS/UIKS Koperasi dan Pedoman Pengawasan KJKS/UJKS Koperasi, sehingga sinergi antara sistem keuangan syariah dengan sektor riil khususnya UMKM diharapkan akan semakin berkembang dengan pesat.

Menkop UKM juga menambahkan, ekonomi free market mecanism tidak memberikan jaminan terhadap hantaman krisis, termasuk krisis keuangan di Eropa dan Amerika. Artinya, bahwa telah teridentifikasi kegagalan terhadap sistem ekonomi kapitalis. Ketidakmampuan sistem ekonomi kapitalis dalam menjawab tantangan kebutuhan masyarakat merupakan sebuah harapan dan angin segar bagi tumbuh dan berkembangnya sistem ekonomi syariah.

\section{Momentem Menggerakkan Usaha Sektor Riil}

Booming perbankan syari'ah selama tahun 2007 sebagai momentum kebangkitan ekonomi syariah. Menurut Majelis Ulama Indonesia (MUI), situasi tersebut sangat tepat dijadikan momentum untuk menggerakkan sektor riil yang saat ini masih belum signifikan lewat perbankan syariah. Rupanya, MUI gerah dengan kondisi perbankan konvensional yang mengendapkan dananya di 
Prospek Ekonomi Syari'ah Melalui Produk Mudarabah

Sertifikat Bank Indonesia (SBI), sehingga fungsi intermediasi perbankan tidak berjalan dengan baik. Realita ini, tidak terjadi di Bank syariah. Tidak heran, jika pertumbuhan perbankan syariah beserta UUS (Unit Usaha Syari'ah) yang lain sejak diperkenalkan beberapa tahun lalu, melaju begitu cepat.

Tentu hal tersebut tidak lepas dari peran semua pihak yang melakukan sosialisasi untuk mempercepat bergeraknya ekonomi syariah dan sektor riil. Melihat potensi dan realita yang terjadi saat ini, ekonomi syariah idealnya dapat tumbuh besar di Indonesia. Selain karena sebagian besar masyarakat negeri ini berpenduduk muslim, juga sistem perbankan syariah dengan konsep bagi hasilnya, sebenarnya sudah dikenal oleh umat Islam dan juga tidak asing bagi masyarakat muslim Indonesia.

Hanya saja, untuk mengembangkan ekonomi syari'ah, perlu strategi sosialisasi dan komunikasi yang terprogram, terintegrasi, dan berkelanjutan serta di dukung oleh buman resources (SDM) yang andal. Selain itu, untuk menumbuhkan awareness (kesadaran) masyarakat terhadap ekonomi syariah, perlu juga dikampanyekan nilai tambah dari sistem ekonomi syariah dibandingkan sistem ekonomi yang ada pada saat ini. Apalagi, produk-produk misal, Unit Usaha Syari'ah (USS) serta perbankan syariah kini sudah sangat beragam. Mulai dari asuransi syariah, pegadaian syariah, leasing syariah, reksadana syariah, pasar modal syariah, saham syari'ah, surat berharga syari'ah (sukuk), jasa umrah dan haji, konsultan manajemen, produk halal, UKM, dan sektor-sektor bisnis lainnya.

\section{Prospek Cerah Ekonomi Syari'ah}

Adalah sebuah kenyataan bahwa LKS (Lembaga Keuangan Syari'ah) serta perbankan syariah semakin unjuk gigi dan meneguhkan eksistensinya dalam percaturan ekonomi dewasa ini. Bahkan perbankan syariah semakin menunjukkan performance yang menggembirakan. Hal ini bisa dilihat dari beberapa indikator antara lain;

Pertama, meningkatnya jumlah nasabah yang menitipkan dananya pada LKS atau bank syari'ah sehingga jumlah kantor cabang UUS dan bank syariah semakin bertambah yang akan berdampak pada peningkatan daya serap tenaga 
kerja yang dibutuhkan. Kedua, tingkat bagi hasil sebagai ikon bank syariah mencapai nilai lebih besar daripada tingkat suku bunga yang berlaku. Ketiga, terhindar dari terpaan krisis moneter disebabkan oleh prinsip yang dikembangkan oleh ekonomi syari'ah tidak mengenal jual beli uang, lebih-lebih bermain saham di pasar uang derivative. Tentu saja hal ini menunjukkan bahwa ekonomi syari'ah lebih tangguh. Sekarang, tinggal bagaimana kesiapan para pengelola UUS (Unit Usaha Syari'ah) dan kalangan perbankan syariah dalam meningkatkan kualitas kinerjanya dengan tetap memperhatikan berbagai kelemahan yang harus segera diperbaiki.

\section{Kelemahan Lembaga Keuangan syariah}

Adapun beberapa kelemahan bank syariah antara lain:

1). Masih terbatasnya pola pembiayaan yang mengarah kepada investasi di sektor riil. Padahal pengembangan sektor riil akan memberikan dampak yang luar biasa terhadap kondisi perekonomian secara keseluruhan. Kita membutuhkan pembukaan lapangan kerja untuk menyerap pengangguran yang mayoritasnya adalah umat Islam. Kita perlu mendirikan industri-industri dan pabrik-pabrik baru yang memungkinkan adanya peningkatan produktivitas barang dan jasa yang dihasilkan. Geliat sektor riil ini harus menjadi perhatian dan concern kita bersama. Kini, sudah saatnya kalangan perbankan syariah memberikan perhatian lebih pada pola pembiayaan selain murababah, yaitu dengan meningkatkan persentase pembiayaan melalui skema mudharabah dan musyarakah²

2). Perbankan syariah membutuhkan suatu investment modes (model investasi) yang berdasarkan pada risk-return modes (model menanggung pengembalian resiko). Untuk menghindari kerugian, maka bank syariah perlu melakukan beberapa langkah, yaitu: diversifikasi portofolio; evaluasi mendalam dan hati-

2 Murabahah adalah: Menjual barang dengan harga pembelian ditambah keuntungan yang disepakati (Al-Kasani, th, Badai' as-Shanai', Juz VII, hal. 198, Beirut: Dar al- Fikr).Mudarabab: Akad antara dua pihak, dimana salah satunya menyerahkan modal uang kepada pihak lain untuk diputar dengan kesepakatan bahwa keuntungannya akan dibagi bersama (Sayid Sabiq, 1970, Fiqh as-Sunnah, Juz III, hal. 202, Beirut: Dar al- Fikr). Musyarakah: Kerja sama antara dua pihak dalam memutar harta untuk memperoleh keuntungan dengan perjanjian bahwa untung rugi akan ditanggung bersama sesuai dengan kesepakatan. 
Prospek Ekonomi Syari'ah Melalui Produk Mudarabah

hati terhadap proyek yang akan dibiayai; serta menelusuri dan menganalisis latar belakang klien yang akan mendapatkan pembiayaan secara cermat. Meski begitu, hingga saat ini, dengan menggunakan pola konsep di atas, belum ada satu bank Islam pun yang mengalami pailit dan kebangkrutan. Berbeda dengan bank konvensional yang tidak jarang mengalami kegagalan dan kebangkrutan dalam perjalanannya.

3). Pembiayaan LKS dan bank syari'ah cenderung menggunakan skema pembiayaan murabahah dan ijarah sebagai model utamanya. Sebagaimana kita ketahui bahwa murabahah adalah kontrak jual ulang terhadap komoditas tertentu, dimana nasabah atau klien meminta kepada pihak bank untuk membeli komoditas tertentu. Kemudian bank pun menjual kembali komoditas tersebut dengan harga baru, yang telah ditambah dengan marjin yang disepakati kedua belah pihak. Tidak dapat dipungkiri bahwa pada kenyataannya, bank-bank Islam papan atas dunia, juga memiliki kecenderungan menjadikan skema murabahah sebagai skema pembiayaan yang utama. Sebagai contoh adalah Bahrain Islamic Bank, Faysal Islamic Bank, Dubai Islamic Bank, Bank Islam Malaysia, Kuwait Finance House, dll, kalau dirata-ratakan, skema murabahah-nya mencapai prosentase lebih dari 70 persen (hasil penelitian dari berbagai mahasiswa di LKS dan Bank Syari'ah).

Meskipun akad murabahah diperbolehkan dalam ekonomi syari'ah, namun ada beberapa kelemahan dalam sistem transaksinya antara lain, a). Skema murabahah, dan juga ijarah, sesungguhnya merupakan fixed return modes, dimana kalau kita mau jujur bahwa yang membedakan secara prinsipil antara bank Islam dan bank konvensional diantaranya adalah terletak pada prinsip risk-profit sharing-nya. Skema murabahah adalah skema yang cenderung tidak beresiko b). Murabahah cenderung menambah bahan bakar kepada kemungkinan terjadinya inflasi, dimana harga komoditas barang cenderung meningkat. c). Skema murabahah tidak memiliki pengaruh yang signifikan terhadap peningkatan produktivitas barang dan jasa. Menurut Syauqi Bek (2012), skema murabahah seharusnya menjadi skema penunjang untuk mengcover pola mudharabah dan musyarakah. Artinya, segala hal yang tidak dapat ditangani oleh skema mudharabah dan musyarakah, baru dapat diatasi dengan skema murabahah. 
4). Masih minimnya pola pembiayaan yang mengarah kepada investasi di sektor riil, padahal pengembangan sektor riil akan memberikan dampak yang luar biasa terhadap kondisi perekonomian secara keseluruhan. Sedangkan kelemahan yang terkait dengan investasi di sektor riil, kalangan perbankan syariah belum memberikan perhatian yang lebih serius terhadap masalah ini. Padahal kita mengenal skema pembiayaan mudharabah dan musyarakah. Jika kita cermati, maka umat dan bangsa ini membutuhkan investasi pada outputproducing sector dengan didirikannya industri-industri dan pabrik-pabrik baru yang memungkinkan adanya peningkatan produktivitas barang dan jasa yang dihasilkan yang akan memberikan efek luar biasa terhadap pembukaan lapangan kerja untuk menyerap pengangguran yang mayoritasnya adalah umat Islam.

\section{Efek Positif Pembiayaan Bagi Hasil}

Ada beberapa efek positif yang timbul jika peningkatan persentase pembiayaan dilakukan melalui pola mudharabah dan musyarakah yaitu:

Pertama, akan menggairahkan sektor riil. Investasi akan meningkat yang disertai dengan pembukaan lapangan kerja baru. Akibatnya tingkat pengangguran akan dapat dikurangi dan pendapatan masyarakat akan bertambah.

Kedua, ditinjau dari sisi nasabah. Nasabah akan memiliki dua pilihan, apakah akan mendepositokan dananya pada bank syariah atau bank konvensional. Nasabah akan membandingkan secara cermat antara expected rate of return yang ditawarkan bank syariah dengan tingkat suku bunga yang ditawarkan oleh bank konvensional. Berdasarkan fakta, selama ini telah membuktikan, bahwa ternyata rate of return bank syariah lebih tinggi bila dibandingkan dengan interest rate (suku bunga) yang berlaku pada bank konvensional. Saat ini prosentase bagi hasil bank syariah mencapai kisaran 8 hingga 9\%/ tahun, masih lebih tinggi bila dibandingkan dengan tingkat suku bunga yang mencapai 5 hingga 6\%/tahun. Dengan demikian, akan menjadi faktor pendorong meningkatnya jumlah nasabah (perspektif marketing (Jur EI) 
Prospek Ekonomi Syariah Melalui Produk Mudarabah

Ketiga, akan mendorong tumbuhnya pengusaha/investor yang berani mengambil keputusan bisnis yang progresif. Hal ini akan memunculkan berkembangnya berbagai inovasi baru, yang pada akhirnya dapat meningkatkan daya saing bangsa ini. Inovasi adalah kata kunci di dalam memenangkan persaingan global.

Keempat, dapat mengurangi peluang terjadinya resesi ekonomi dan krisis keuangan. Hal ini dikarenakan bank syariah adalah institusi keuangan yang berbasis aset (asset-based). Artinya, bank syariah adalah institusi yang berbasis produksi (production based), dengan transaksi berdasarkan aset riil dan bukan mengandalkan pada kertas kerja semata yang bersifat derivative. Lain halnya dengan bank konvensional yang bertransaksi berdasarkan paper work dan dokumen semata, bahkan transaksi (jual beli) uang (modal) yang setiap detik berubah sehingga berakibat terjadi ketidakpastian dan seakan sebagai ajang untung- untungan atau perjudian (maisir), yang ujung-ujungnya membuat manusia tidak dapat tenang dikarenakan adanya kehawatiran akan tertimpa anjloknya harga saham yang dijualnya di pasar saham secara derivative.

Pola pembiayaan mudharabah dan musyarakah adalah pola pembiayaan yang berbasis pada produksi. Krisis keuangan pun dapat diminimalisir karena balance sheet perusahaan relatif stabil. Hal ini dikarenakan posisinya sebagai mudharib, di mana perusahaan tidak menanggung kerugian yang ada, apabila kerugian tersebut disebabkan oleh kondisi luar biasa yang tidak diprediksikan sebelumnya, misalnya diakibatkan oleh bencana alam. Maksudnya, keadaan tersebut terjadi secara tidak sengaja dan diluar batas kemampuan manusia. Dengan demikian, semua beban kerugian akan ditanggung oleh bank syariah sebagai rabbul maal.

Kelima, pola pembiayaan mudharabah dan musyarakah adalah pola pembiayaan yang berbasis pada produksi. Krisis keuangan pun dapat diminamilisir karena balance sheet perusahaan relatif stabil. Hal ini dikarenakan posisinya sebagai mudarib, dimana perusahaan tidak menanggung kerugian yang ada, apabila kerugian tersebut disebabkan oleh kondisi luar biasa yang tidak diprediksikan sebelumnya, misalnya diakibatkan oleh bencana alam. Maksudnya, keadaan tersebut terjadi secara tidak sengaja dan diluar batas kemampuan. Dengan 
demikian, semua beban kerugian akan ditanggung oleh bank syariah sebagai rabbul maal.

Keenam, pola mudharabah dan musyarakah dapat menjadi solusi alternatif atas problem overlikuiditas yang saat ini terjadi. karena bank tidak melempar saham ke pasar uang derivative serta tingkat kehati-hatiannya, menjadikan dana yang dikelolanya sering pada posisi overlikuiditas. Hal ini akan mengurangi problem krisis keuangan baik pada ranah domestik maupun pada tingkat global. Kondisi overlikuiditas ini harus disiasati dengan menyalurkannya pada usaha sektor riil. Melalui pembiayaan berdasarkan skema mudharabah dan musyarakah. ekonomi syari'ah terutama melalui LKS dan bank syari'ah-nya dapat berperan lebih signifikan didalam upaya pengembangan dan peningkatan perekonomian nasional saat ini dan mendatang.

\section{Alternatif Kebijakan Sektor Riil Syariah}

Pertumbuhan sektor riil perekonomian nasional tampaknya tetap menjadi tantangan utama pemerintah memasuki tahun 2014 meskipun Pemerintah optimistis terhadap prospek ekonomi nasional didasarkan pada angka pertumbuhan ekonomi nasional 2013 yang direncanakan naik menjadi 7 persen serta Indeks Harga Saham Gabungan (IHSG) yang tumbuh 52 persen sampai awal tahun 2013. Namun, dengan memburuknya kondisi makro yang tidak diimbangi dengan pertumbuhan sektor riil. Akibatnya, sejumlah persoalan terutama pengangguran dan kemiskinan masih menjadi pekerjaan rumah pemerintah. Dalam sebuah survei terungkap bahwa kepuasan rakyat terhadap kinerja tim ekonomi pemerintah terus menurun, bahkan mencapai 55 persen. Belum lagi dengan evaluasi sejumlah parpol yang memberi rapor merah pada kinerja menteri-menteri ekonomi. Terlepas dari pro dan kontra serta kepentingan politik, Untuk itu, diperlukan sejumlah terobosan kebijakan pemerintah terkait dengan upaya mengembangkan sektor riil. 
Prospek Ekonomi Syari'ah Melalui Produk Mudarabah

\section{Dua (2) langkah kebijakan.}

\section{Kebijakan pertama}

a) Selain dukungan dari sumber Anggaran Pendapatan Belanja Negara (APBN) untuk usaha sektor riil, melalui penguatan peran intermediasi perbankan nasional dalam pembiayaan dan investasi sektor riil. Tampaknya peran perbankan nasional terhadap investasi di sektor riil masih perlu dioptimalkan. Untuk memperkuat posisi lembaga keuangan syariah dan instrumen pembiayaan syariah yang ada, perlu sinergitas antara LKS dengan LKK, karena semua jenis transaksi dan produk keuangan syariah memiliki korelasi yang sangat kuat dengan sektor riil. Untuk merealisasikannya, diperlukan sejumlah terobosan untuk mengalirkan dana menganggur yang disimpan di SBI (Sertifikat Bank Indonesia) dan SWBI (Sertifikat Wadi'ah Bank ndonesia) ke sektor riil. Menurut Syauqi (2012), ada sejumlah alternatif yang dapat dilakukan antara lain 1). BI menetapkan batas maksimal pembelian SBI dan SWBI. Misalnya, BI mewajibkan dalam portofolio investasi bank konvensional dan syariah, investasi di SBI dan SWBI maksimal lima persen. 2), jika bank masih kelebihan likuiditas dan mereka bermaksud membeli obligasi, mereka dapat diwajibkan membeli sukuk (Surat Berharga Syariah) baik sukuk negara maupun sukuk korporasi, dengan persentase minimal tertentu.

Misalnya, persentase minimal pembelian sukuk negara 50 persen. Dengan sukuk, dipastikan dana tersebut akan mengalir ke sektor riil. Bagi bank, yang membedakannya dengan SBI/SWBI adalah pada return-nya karena return sukuk sangat bergantung pada pola transaksinya.

b) Kemampuan pemerintah menyiapkan sejumlah proyek investasi riil yang mampu menyerap dana dalam jumlah besar sekaligus memiliki prospek yang baik.

c) Kesiapan BI (Bank Indonesia) dan kalangan industri perbankan sendiri, terutama bank konvensional. Hal ini bisa jadi akan mengundang reaksi mengingat return yang akan mereka terima dari pembelian sukuk menjadi tidak pasti, sedangkan mereka memiliki kewajiban tetap membayar bunga kepada nasabah. 
Guna memperoleh informasi tentang hukum ekonomi syari'ah secara progresif, perlu kajian fikih secara komprehensif tentang boleh tidaknya sumber dana sukuk berasal dari bank konvensional (tugas mahassiwa Jurusan Muamalah).

\section{Kebijakan kedua:}

a) Membuat linkage bank syariah (BUS/UUS) dengan BPRS, BMT, dan koperasi syariah. Banyak pola linkage dapat dibuat, bergantung pada situasi dan kebutuhan. Misalnya, antara BUS/UUS dengan BPRS dibuat pola kerja sama berbasis mudarabah muqayyadah dengan BUS/UUS bertindak sebagai shabibul maal dan BPRS sebagai mudarib-nya. BPRS yang akan menyalurkan pembiayaan ke berbagai pelosok kecamatan dan desa. BPRS juga bisa membuat link dengan BMT/koperasi syariah dengan pola sama atau BUS/UUS langsung membuat link dengan BMT/koperasi syariah. Pemerintah dan BI harus mendorong proses sinergi itu.

b) Optimalisasi Zakat, Infaq dan Waqaf.

Pemerintah dapat pula memanfaatkan instrumen zakat, infaq, dan waqaf. Ada sejumlah kebijakan yang dapat dilakukan. Pertama, mengoptimalkan potensi dana BUMN. Menneg BU MN dapat mengeluarkan kebijakan pemanfaatan dana tersebut melalui sinergi dengan lembaga-lembaga lain, seperti BAZNAS. Kedua, meningkatkan optimalisasi penghimpunan dan pendayagunaan zakat. Zakat memiliki dampak nyata terhadap perekonomian jika realisasi potensi zakat dapat berjalan optimal. Ketiga, memanfaatkan instrumen waqaf, termasuk waqaf tunai. Pemerintah juga harus memikirkan integrasi aset waqaf dengan bursa syariah yang memiliki potensi sangat besar. Sebagai contoh, luas tanah wakaf di Indonesia $1.400 \mathrm{~km} 2$ dengan nilai lebih dari Rp 590 triliun (Syauqi, 2012).

Aset tersebut berpotensi untuk menarik investasi. Sebagaimana negara Arab Saudi dan Singapura, kedua negara tersebut telah memberi contoh mengintegrasikan aset waqaf dengan bursa melalui instrumen sukuk. Demikian pula dengan waqaf tunai. Badan Waqaf Indonesia (BWI) sudah saatnya didorong lebih proaktif mengembangkan waqaf tunai. Misalnya, BWI bekerja sama dengan BI (Bank Indonesia) dan bank syariah dalam penghimpunan waqaf tunai dan bersinergi dengan BAZNAS dalam pendayagunaannya. 
Prospek Ekonomi Syariah Melalui Produk Mudarabah

Hingga kini, meskipun kondisi ekonomi makro terus membaik, tetapi pada kenyataannya kurang diimbangi dengan pertumbuhan sektor ekonomi riil. Begitu juga peran perbankan nasional terhadap investasi di sektor riil belum optimal secara signifikan. Untuk itu dalam rangka meningkatkan usaha ekonomi sektor riil perlu adanya peningkatan kerjasama antara BUMN dengan BAZNAS dan BWI, sehingga peran ekonomi Syari'ah dalam meningkatkan kesejahteraan ekonomi umat segera dapat lebih meningkat di masa-masa mendatang. Amin. 


\section{DAFTAR PUSTAKA}

Ahmad Qadri Abdillah Azizi., 2003, Membangun Fondasi Ekonomi Umat, Yogyakarta: Pustaka Pelajar

Anom Surya Putra., 2002, Bank Syariah, Antara Hukum, Ekonomi dan Politik, Semarang: Jurnal Justisia Edisi XX/XII/2002.

Irfan Syauqi Bek., 2012, Ekonomi Syari'ah dan Penguatan Sektor Rïl, Artikel diakses 22 Juli 2012, http://www.ekonomi

Monzer Kahf., 1978, Islamic Economic System; A Review, Indiana: Al- Ittihad.

Musthafa Edwin Nasution., 2006, Pengenalan Eksklusif Ekonomi Islam, Jakarta: Kencana Prenada Media Group.

Syed Nawab Haidar Naqvi., 2003, Menggagas Imu Ekonomi Islam, Yogyakarta: Pustaka Pelajar.

Sumber:

http:/ / www.pesantrenvirtual.com/index.php?Itemid=60\&catid=8:kaj ian-ekonomi\&id=1205:alternatif-kebijakan-sektor-riil-

syariah\&option $=$ com content $\& v i e w=$ article

Tribunnews.com - Jumat, 17 Agustus 2012 07:22 WIB.

Maktabah Syamilah, Edisi tahun 1998. 
Prospek Ekonomi Syari'ah Melalui Produk. Mudarabah 


\section{UCAPAN TERIMAKASIH}

Redaksi Jurnal Economica mengucapkan terimakasih yang sebesarbesarnya kepada Mitra Bestari yang membantu terwujudnya penerbitan Jurnal Economica Volume IV/ Edisi 1/ Mei 2013:

1. Muhibbin

2. Ahmad Rofiq

3. Muijiono

4. Muslich Shobir 